\title{
Glycerol transport and phosphoenolpyruvate- dependent enzyme I- and HPr-catalysed phosphorylation of glycerol kinase in Thermus flavus
}

\author{
Emmanuelle Darbon, ${ }^{1}$ Kiyoshi Ito, ${ }^{2}$ Hua-Shan Huang, ${ }^{2}$ \\ Tadashi Yoshimoto, ${ }^{2}$ Sandrine Poncet ${ }^{1}$ and Josef Deutscher ${ }^{1}$
}

Author for correspondence: Josef Deutscher. Tel: +331308154 47. Fax: +33130815457. e-mail: jdeu@platon.grignon.inra.fr

1 Laboratoire de Génétique des Microorganismes, INRA-CNRS URA 1925, F78850 Thiverval-Grignon, France

2 School of Pharmaceutical Sciences, Nagasaki University, Nagasaki 852 , Japan

\begin{abstract}
The genes $g / p K$ and $g / p F$, encoding glycerol kinase and the glycerol facilitator of Thermus flavus, a member of the Thermus/Deinococcus group, have recently been identified. The protein encoded by $g / p K$ exhibited an unusually high degree of sequence identity $(80.6 \%)$ when compared to the sequence of glycerol kinase from Bacillus subtilis and a similar high degree of sequence identity $(64.8 \%)$ was observed when the sequences of the glycerol facilitators of the two organisms were compared. The work presented in this paper demonstrates that $T$. flavus is capable of taking up glycerol, that $g / p F$ and $g / p K$ are expressed constitutively and that glucose exerts a repressive effect on the expression of these genes. T. flavus was found to possess the general components of the phosphoenolpyruvate (PEP) : sugar phosphotransferase system (PTS) enzyme I and histidine-containing protein (HPr). These proteins catalyse the phosphorylation of $T$. flavus glycerol kinase, which contains a histidyl residue equivalent to His-232, the site of PEP-dependent, PTS-catalysed phosphorylation in glycerol kinase of Enterococcus casseliflavus. Purified glycerol kinase from $T$. flavus could also be phosphorylated with enzyme I and HPr from B. subtilis. Similar to enterococcal glycerol kinases, phosphorylated $T$. flavus glycerol kinase exhibited an electrophoretic mobility on denaturing and non-denaturing polyacrylamide gels that is different from the electrophoretic mobility of non-phosphorylated glycerol kinase. However, in contrast to PEPdependent phosphorylation of enterococcal glycerol kinases, which stimulated glycerol kinase activity about 10-fold, phosphorylation of $T$. flavus glycerol kinase caused only a slight increase in enzyme activity.
\end{abstract}

Keywords: Thermus flavus, glycerol metabolism, glycerol kinase, PEP : sugar phosphotransferase system

\section{INTRODUCTION}

Glycerol enters bacterial cells by an energy-independent diffusion process catalysed by an integral membrane protein, the glycerol facilitator (Lin, 1976; Heller et al., 1980). Intracellular glycerol is subsequently converted by the enzyme glycerol kinase to glycerol 3-phosphate,

\footnotetext{
Abbreviations: HPr, histidine-containing protein; MTP, multiphosphoryl transfer protein; PEP, phosphoenolpyruvate; PTS, phosphoenolpyruvate : sugar phosphotransferase system.
}

the inducer of the $g l p$ operon in many bacteria. Glycerol 3-phosphate is not a substrate of the glycerol facilitator and hence remains trapped in the cell, where it is further metabolized. Although glycerol is not transported by the phosphoenolpyruvate (PEP) : sugar phosphotransferase system (PTS), mutants of Gram-positive and Gramnegative bacteria defective in one of the general components of the PTS, enzyme I or histidine-containing protein (HPr), were unable to grow on glycerol as the sole carbon source (Saier et al., 1976; Reizer et al., 1984; Romano et al., 1990; Gonzy-Treboul et al., 1991; Beijer \& Rutberg, 1992). The PTS seems therefore to 
play an important role in the regulation of glycerol metabolism in numerous bacteria. The mechanisms involved in this regulation are different in Gram-positive and Gram-negative bacteria, but they are both mediated via glycerol kinase. In Gram-negative bacteria such as Escherichia coli or Salmonella typhimurium, EIIA Gle was found to interact with glycerol kinase (Hurley et al., 1993) and to inhibit its activity (De Boer et al., 1986; van der Vlag et al., 1994) leading to reduced uptake of glycerol. In contrast, phosphorylated EIIA ${ }^{\text {Gle }}$ had no inhibitory effect on glycerol kinase activity. In Grampositive bacteria such as Enterococcus faecalis and Enterococcus casseliflavus, glycerol kinase was found to be phosphorylated by PEP, enzyme I and $\mathrm{HPr}$, and phosphorylation caused an $\sim 10$-fold increase of glycerol kinase activity (Deutscher, 1985; Deutscher \& Sauerwald, 1986; Charrier et al., 1997). This phosphorylation is reversible, and phosphorylated glycerol kinase is dephosphorylated probably by transferring its phosphoryl group to HPr when a rapidly metabolizable PTS substrate is present in the growth medium leading to dephosphorylation of the PTS proteins (Deutscher et al., 1993). Recently, His-232 of glycerol kinase from Ent. casseliflavus has been identified as the site of PEPdependent phosphorylation (Charrier et al., 1997). In glycerol kinase of Bacillus subtilis, the equivalent His230 is probably also phosphorylated. Mutants in which His-230 had been replaced with an arginine or in which the neighbouring Phe-232 had been replaced with a serine were able to grow on glycerol as the sole carbon source, even when the general PTS proteins enzyme I and $\mathrm{HPr}$ were not functional (Wehtje et al., 1995). Glycerol kinase in these mutants was therefore assumed to possess elevated activity, rendering glycerol uptake and metabolism independent of PTS-mediated activation by phosphorylation. This could indeed be confirmed for the His-232-Arg mutant glycerol kinase of Ent. casseliflavus, which exhibited much higher activity than the wild-type enzyme (Charrier et al., 1997). An amino acid sequence comparison with known glycerol kinase sequences derived from Gram-positive and Gram-negative bacteria revealed that these enzymes exhibit sequence identities ranging from about 40 to $60 \%$ when compared to each other, but that the phosphorylatable histidyl residue and the flanking sequences are well-conserved only in glycerol kinases of Gram-positive bacteria, whereas an equivalent of the phosphorylatable histidyl residue is absent from glycerol kinases of Gram-negative bacteria such as Esc. coli and Haemophilus influenzae (Charrier et al., 1997).

Recently, $g l p K$, the gene encoding glycerol kinase, and a fragment of $g l p F$, which encodes the first 156 amino acids of the glycerol facilitator of Thermus flavus, have been cloned and sequenced (Huang et al., 1998a). Surprisingly, the thermostable glycerol kinase from $T$. flavus, which belongs to the Thermus/Deinococcus group, showed an unusually high degree of sequence identity $(80 \cdot 6 \%)$ when compared to glycerol kinase of $B$. subtilis and $64.0 \%$ when compared to glycerol kinase of Ent. casseliflavus. An equivalent of His-232, the site of
PEP-dependent phosphorylation in glycerol kinase from Ent. casseliflavus, is present in glycerol kinase of $T$. flavus and the surrounding sequence is well-conserved. We therefore wanted to study whether T. flavus is capable of transporting glycerol and whether glucose exerts a repressive effect on glycerol transport and metabolism. We also wanted to test whether T. flavus possesses the general PTS components enzyme I and HPr allowing PEP-dependent phosphorylation of purified $T$. flavus glycerol kinase, whether purified enzyme I and HPr from B. subtilis can phosphorylate T. flavus glycerol kinase and whether this PEP-dependent phosphorylation would have an influence on $T$. flavus glycerol kinase activity.

\section{METHODS}

Strains and growth conditions. T. flavus strain TE3420 (DSM 674) (Huang et al., 1998a) was obtained from the Deutsche Sammlung von Mikroorganismen und Zellkulturen $\mathrm{GmbH}$, Braunschweig, Germany. It was grown with shaking at $50^{\circ} \mathrm{C}$ in $2 \times$ YT medium (Sambrook et al., 1989) in the absence of carbohydrates or in the presence of either $1 \%$ glycerol, $1 \%$ glucose, or $1 \%$ glycerol plus $1 \%$ glucose. Esc. coli strains M15 (containing the plasmid pREP4; Qiagen) and DH5 $\alpha$ (containing plasmid pGYK12) (Huang et al., 1997, 1998a) were grown at $37{ }^{\circ} \mathrm{C}$ in Luria-Bertani (LB) medium (Sambrook et al., 1989). For the growth of cells transformed with the plasmids pREP4 and either pAG2 or pAG3 (Galinier et al., 1997), the LB medium also contained $25 \mu \mathrm{g}$ kanamycin $\mathrm{ml}^{-1}$ and $100 \mu \mathrm{g}$ ampicillin $\mathrm{ml}^{-1}$.

Protein purification. Recombinant $T$. flavus glycerol kinase was produced in the Esc. coli strain DH5 $\alpha$ transformed with plasmid pGYK12 and purified by sequential chromatography on DEAE-Toyopearl and Toyopearl HW650 columns as previously described (Huang et al., 1997, 1998a). The Esc. coli strain M15 carrying the plasmid pREP4 (Qiagen) and transformed with plasmids pAG2 or pAG3 was used for the overproduction of B. subtilis His-tagged HPr and His-tagged enzyme I, respectively (Galinier et al., 1997).

Glycerol-transport assay. A $150 \mathrm{ml}$ culture of T. flavus TE3420 cells was grown to mid-exponential phase and cells were harvested by centrifugation at $4{ }^{\circ} \mathrm{C}$, washed twice with $\mathrm{MM}$ medium (Anagnostopoulos \& Spizizen, 1961) and resuspended in the same medium at a concentration corresponding to an $\mathrm{OD}_{600}$ of 2 . A peptone solution was added $(1 \%$ final concentration) and the mixture was prewarmed at $50^{\circ} \mathrm{C}$ for $10 \mathrm{~min}$ before $\left[1,3{ }^{14} \mathrm{C}\right]$ glycerol $[\mathrm{ICN} ; 0.5 \mathrm{mM}$ final concentration, specific activity, $0.5 \mathrm{mCi}(18.5 \mathrm{MBq}) \mathrm{mmol}^{-1}$ ] was added. Aliquots $(120 \mu \mathrm{l})$ were withdrawn at different time intervals $(0 \cdot 5,1 \cdot 5,3,5,10,15$ and $20 \mathrm{~min})$, filtered through a $0.45 \mu \mathrm{m}$ pore-size filter and washed twice with $5 \mathrm{ml}$ cold Tris/maleate buffer, $\mathrm{pH} 7 \cdot 4$. The filters were dried and the radioactivity retained was determined by liquid scintillation counting.

Protein-phosphorylation assays. Phosphorylation of purified $T$. flavus glycerol kinase with crude extracts prepared from $T$. flauus cells was carried out with $\left[{ }^{32} \mathrm{P}\right] \mathrm{PEP}$, which was prepared from $\left[\gamma^{32} \mathrm{P}\right]$ ATP via the pyruvate kinase exchange reaction at equilibrium (Roossien et al., 1983). T. flavus cells were grown in $150 \mathrm{ml} 2 \times$ YT medium in the absence of a carbohydrate or in the presence of $1 \%$ glycerol, $1 \%$ glucose or $1 \%$ fructose to $\mathrm{OD}_{600}$ between 0.65 and $0 \cdot 70$. Cells were centrifuged, washed 
three times with $50 \mathrm{mM}$ Tris $/ \mathrm{HCl}$ buffer, $\mathrm{pH} 7 \cdot 4$, resuspended in $2 \mathrm{ml}$ of the same buffer and broken by sonication. Cell debris was removed by centrifugation and the supernatant was dialysed overnight against $50 \mathrm{mM}$ Tris $/ \mathrm{HCl}, \mathrm{pH} 7 \cdot 4$, containing $0 \cdot 1 \mathrm{mM}$ PMSF and $0 \cdot 1 \mathrm{mM}$ DTT. Phosphorylation of glycerol kinase was carried out in a reaction mixture of $30 \mu \mathrm{l}$ containing $4 \mu \mathrm{g}$ T. flavus glycerol kinase, $10 \mathrm{mM} \mathrm{MgCl}$, $10 \mu \mathrm{M}\left[{ }^{32} \mathrm{P}\right] \mathrm{PEP}(0 \cdot 1 \mu \mathrm{Ci} ; 3.7 \mathrm{kBq}), 50 \mathrm{mM}$ Tris/ $\mathrm{HCl}$ buffer, $\mathrm{pH} 7 \cdot 4$, and $6 \mu \mathrm{l} \mathrm{T}$. flavus crude extracts. The assay mixture was incubated for $20 \mathrm{~min}$ at $37^{\circ} \mathrm{C}$. The phosphorylation reaction was stopped by adding an equal volume of sample buffer (Laemmli, 1970) to the assay mixtures. Phosphorylation assays with $T$. flavus glycerol kinase and purified $B$. subtilis enzyme $\mathrm{I}(\mathrm{His})_{6}$ and $\mathrm{HPr}(\mathrm{His})_{6}$ were also carried out in a total volume of $30 \mu \mathrm{l}$ and incubated for $20 \mathrm{~min}$ at $37^{\circ} \mathrm{C}$. They contained $4 \mu \mathrm{g}$ T. flavus glycerol kinase, $0.5 \mu \mathrm{g}$ B. subtilis enzyme $\mathrm{I}(\mathrm{His})_{6}, 0.5 \mu \mathrm{g}$ B. subtilis $\mathrm{HPr}(\mathrm{His})_{6}, 10 \mathrm{mM} \mathrm{MgCl}_{2}$, $10 \mathrm{mM}$ PEP or $10 \mu \mathrm{M}\left[{ }^{32} \mathrm{P}\right] \mathrm{PEP}(0 \cdot 1 \mu \mathrm{Ci} ; 3.7 \mathrm{kBq})$ and $50 \mathrm{mM}$ Tris/ $\mathrm{HCl}$ buffer, $\mathrm{pH} 7 \cdot 4$. Proteins were separated by PAGE performed either under denaturing ( $1 \%$ SDS) or non-denaturing conditions. Gels were dried and exposed to x-ray film (Biomax MR, Kodak) for experiments carried out with $\left[{ }^{32} \mathrm{P}\right] \mathrm{PEP}$ or stained with Coomassie brilliant blue $\mathrm{R}$ for experiments with non-radioactive PEP.

Enzyme-activity assays. Glycerol kinase activity was determined by using a coupled spectrophotometric assay carried out in $100 \mathrm{mM}$ glycine/hydrazine buffer, pH 8.8 (Deutscher \& Sauerwald, 1986). Enzyme activities are expressed as nmol product formed $\min ^{-1}$ and $(\mu \mathrm{g} \text { protein })^{-1}$. To measure the effect of phosphorylation on the enzyme activity, glycerol kinase $(6.4 \mu \mathrm{g})$ was first incubated for $20 \mathrm{~min}$ at $37^{\circ} \mathrm{C}$ together with $10 \mathrm{mM}$ PEP, $10 \mathrm{mM} \mathrm{MgCl}_{2}, 1 \mu \mathrm{g}$ enzyme $\mathrm{I}(\mathrm{His})_{6}$ and $1 \mu \mathrm{g}$ $\mathrm{HPr}(\mathrm{His})_{6}$ in a total volume of $60 \mu \mathrm{l}$. An aliquot of $7 \cdot 5 \mu \mathrm{l}$ of the reaction mixture (corresponding to $0.5 \mu$ g glycerol kinase) was used for the glycerol kinase assay. To determine to what extent glycerol kinase used in these enzymic tests was phosphorylated, the proteins present in a $30 \mu \mathrm{l}$ aliquot of the glycerol kinase phosphorylation mixture were separated on a denaturing $10 \%$ polyacrylamide gel.

The presence of enzyme I and HPr in crude extracts of $T$. flavus has been demonstrated with the Staphylococcus aureus mutant complementation assay by using crude extracts prepared from the mutants S710A (ptsI lacR) and S797A ( $p t s H$ lacR) (Hengstenberg et al., 1969).

\section{RESULTS}

\section{T. flavus is capable of taking up glycerol}

We first wanted to test whether T. flavus is able to transport glycerol. For this purpose, $T$. flavus cells were grown in $2 \times$ YT medium or $2 \times$ YT medium containing glycerol, glucose or glycerol plus glucose. Cells grown in $2 \times$ YT or $2 \times$ YT containing glycerol were found to transport glycerol effectively (Fig. 1), suggesting that the $T$. flavus $g l p F$ gene and the adjacent glpK gene, which encode the glycerol facilitator and glycerol kinase, respectively, and which were found to be organized in an operon (Huang et al., 1998a), are expressed constitutively. In contrast, cells grown in $2 \times \mathrm{YT}$ medium containing either glucose or glucose plus glycerol exhibited strongly reduced glycerol uptake, indicating that a carbon-catabolite repression mechanism is operative in $T$. flavus.

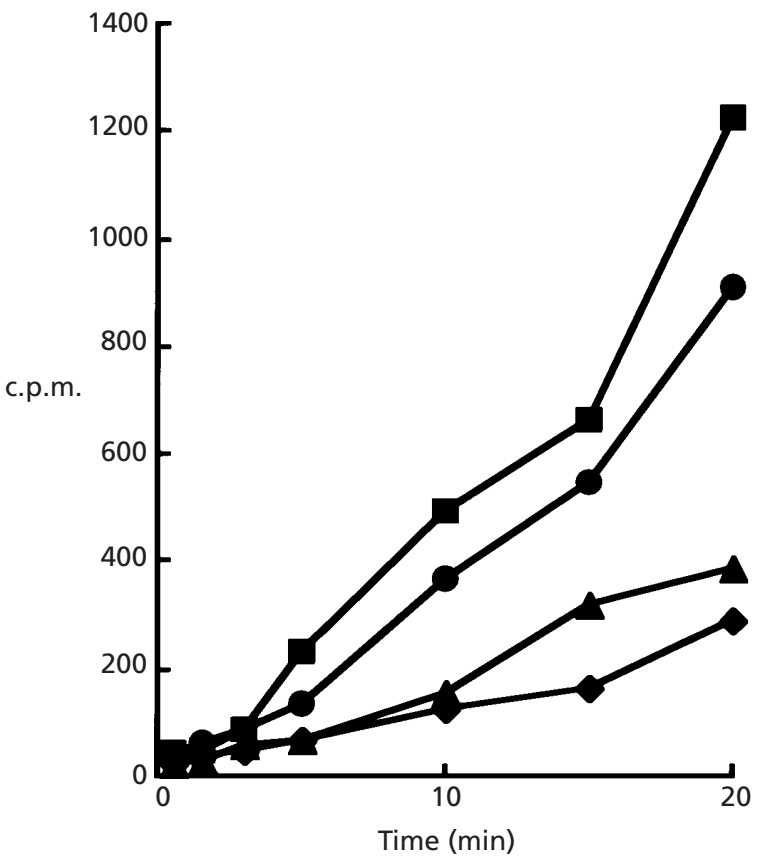

Fig. 1. Uptake of $\left[{ }^{14} \mathrm{C}\right]$ glycerol by $T$. flavus cells. Cells were grown in $2 \times$ YT medium without an additional carbon source $(\square)$ or with $1 \%$ glycerol $(\bullet), 1 \%$ glucose $(\diamond)$ or $1 \%$ glycerol plus $1 \%$ glucose $(\boldsymbol{\Delta})$. Glycerol-transport studies were carried out in $\mathrm{MM}$ medium containing $1 \%$ peptone and $0.5 \mathrm{mM}[1,3-$ ${ }^{14}$ C]glycerol $\left[0.5 \mathrm{mCi}(18.5 \mathrm{MBq}) \mathrm{mmol}^{-1}\right]$ as described in Methods.

\section{Purified T. flavus glycerol kinase can be phosphorylated by crude extracts prepared from $T$. flavus cells}

Since the glycerol kinases from T. flavus (Huang et al., 1998a) and Thermus aquaticus (Huang et al., 1998b) exhibit an unusually high degree of sequence identity when compared to glycerol kinase from Ent. casseliflavus (about $65 \%$ ) or B. subtilis (more than $80 \%$ ), and since the sequence around the histidyl residue representing the site of PEP-dependent phosphorylation in glycerol kinases of Gram-positive bacteria is wellconserved in glycerol kinase from T. flavus (Fig. 2), we wanted to test whether T. flavus possesses enzyme I and $\mathrm{HPr}$ capable of catalysing the PEP-dependent phosphorylation of purified $T$. flavus glycerol kinase. To determine whether enzyme I and HPr are present in $T$. flavus, we carried out a mutant-complementation assay with crude extracts from the $S$. aureus $p t s I$ lacR mutant S710A or the ptsH lacR mutant S797A, respectively. Crude extracts from $T$. flavus cells grown on $2 \times \mathrm{YT}$ were capable of restoring PTS-catalysed ONPG phosphorylation in both $S$. aureus mutants (data not shown), confirming that $T$. flawus must possess enzyme I and HPr. The positive results suggested also that enzyme I and HPr from T. flavus resemble their Gram-positive homologues since the corresponding proteins of Gramnegative bacteria are not functional in the $S$. aureus mutant-complementation assay (Kalbitzer et al., 1982). 


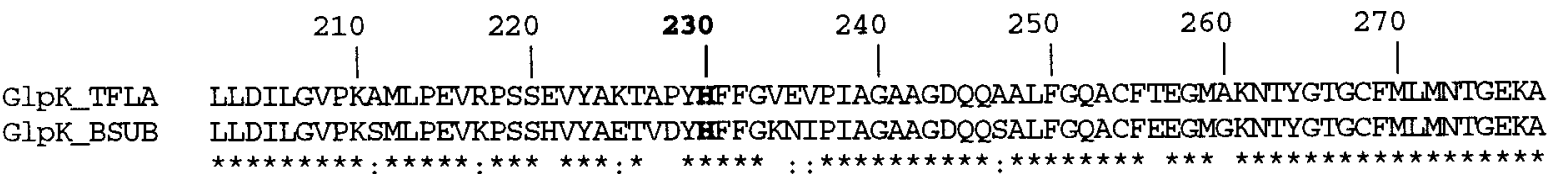

Fig. 2. Alignment of the sequences flanking the histidyl residues in glycerol kinase from $T$. flavus (TFLA) (Huang et al., 1998a) and B. subtilis (BSUB) (Holmberg et al., 1990) which are equivalent to the phosphorylatable histidyl residues in glycerol kinase from Ent. casseliflavus (Charrier et al., 1997). The numbering refers to the sequence of the $B$. subtilis protein. The phosphorylatable histidyl residues are shown in bold. Identical amino acids are indicated by stars, conservative changes by colons.

To test whether T. flavus enzyme I and HPr would be capable of phosphorylating the glycerol kinase of this organism, $T$. flavus cells were grown in $2 \times$ YT medium in the absence of a carbohydrate or in the presence of $1 \%$ glycerol, $1 \%$ glucose or $1 \%$ fructose and crude extracts were prepared from these cells as described in Methods. These crude extracts were used for PEPdependent phosphorylation assays. After incubation with $\left[{ }^{32} \mathrm{P}\right] \mathrm{PEP}$ in the absence of purified glycerol kinase, four major phosphorylated proteins were found to be present in crude extracts of $T$. flavus cells grown in $2 \times$ YT medium or $2 \times$ YT medium containing either glycerol or fructose (Fig. 3a, lanes 3, 5 and 9). Two of these labelled bands migrated similarly to the B. subtilis enzyme I and HPr standards (Fig. 3a, lane 1) and probably represent the corresponding $T$. flavus proteins. The third labelled band migrated just below the presumed enzyme I band, while the fourth band migrated according to a molecular mass of $55 \mathrm{kDa}$, which is in good agreement with the molecular mass calculated for glycerol kinase monomers from $T$. flavus. While the first three labelled bands exhibited similar intensities in glucose-grown cells, the intensity of the fourth band was clearly reduced in glucose-grown cells (Fig. 3a, lane 7). However, the intensity of the radioactive band migrating according to a molecular mass of $55 \mathrm{kDa}$ was greatly increased when purified $T$. flavus glycerol kinase was added to the phosphorylation assays with the various crude extracts (Fig. 3a, lanes 2, 4, 6 and 8). These results establish that $T$. flavus possesses the general PTS components enzyme I and $\mathrm{HPr}$ and that these two proteins are capable of phosphorylating $T$. flavus glycerol kinase.

\section{Purified $T$. flavus glycerol kinase can be phosphorylated by enzyme I and HPr from B. subtilis}

As the general PTS components of T. flavus are not available in purified form and as T. flavus glycerol kinase exhibits the strongest homology to glycerol kinase from B. subtilis (more than $80 \%$ sequence identity), we wanted to test whether T. flavus glycerol kinase could be phosphorylated with PEP in the presence of enzyme $\mathrm{I}(\mathrm{His})_{6}$ and $\mathrm{HPr}(\mathrm{His})_{6}$ from $B$. subtilis. PEPdependent phosphorylation of T. flavus glycerol kinase catalysed by enzyme I and HPr of B. subtilis was demonstrated either by phosphorylation with $\left[{ }^{32} \mathrm{P}\right] \mathrm{PEP}$ followed by separation on an SDS-polyacrylamide gel and autoradiography or by phosphorylation in the presence of $10 \mathrm{mM}$ PEP followed by separation on either denaturing or nondenaturing polyacrylamide gels. Using $\left[{ }^{32} \mathrm{P}\right] \mathrm{PEP}$, we could demonstrate that purified T. flavus glycerol kinase was phosphorylated in the presence of PEP, enzyme I(His) ${ }_{6}$ and $\mathrm{HPr}(\mathrm{His})_{6}$ (Fig. 3b, lane 4). No radioactive band corresponding to phosphorylated glycerol kinase appeared when either enzyme $\mathrm{I}(\mathrm{His})_{6}$ or $\mathrm{HPr}(\mathrm{His})_{6}$ were absent (Fig. 3b, lanes 5 and 7), confirming that phosphorylation of $T$. flavus glycerol kinase requires both general PTS proteins. Similar to enterococcal glycerol kinases (Deutscher, 1985; Charrier et al., 1997), the phosphorylated and unphosphorylated forms of $T$. flavus glycerol kinase were found to migrate to different positions during SDS-PAGE (Fig. 3c, lanes 1 and 4). The more slowly migrating band corresponding to phosphorylated glycerol kinase was absent when either HPr, enzyme I or PEP were missing in the reaction mixture (Fig. 3c, lanes 2, 3 and 5). Phosphorylated and unphosphorylated T. flavus glycerol kinase also exhibited a different electrophoretic mobility when they were separated on non-denaturing polyacrylamide gels, where phosphorylated glycerol kinase was found to migrate faster than unphosphorylated glycerol kinase (Fig. 3d, lanes 1 and 4). Again, the band corresponding to phosphorylated glycerol kinase was absent when either HPr, enzyme I or PEP were missing in the reaction mixture (Fig. 3d, lanes 2, 3 and 5). In phosphorylation assays containing PEP at concentrations higher than $10 \mu \mathrm{M}$, only the faster-migrating band corresponding to phosphorylated glycerol kinase could be observed. With PEP at concentrations lower than $1 \mu \mathrm{M}$, only the band corresponding to unphosphorylated glycerol kinase was visible (data not shown). Interestingly, three bands corresponding to three different forms of glycerol kinase could be observed when a PEP concentration between 1 and $8 \mu \mathrm{M}$ was used for the phosphorylation assays (Fig. $3 \mathrm{~d}$, lane 6). Under these conditions, only some of the glycerol kinase molecules could be phosphorylated, and in addition to the two bands migrating to the positions of unphosphorylated and completely phosphorylated glycerol kinase, a third band migrating between these two bands could be observed. In contrast, only bands corresponding to phosphorylated and unphosphorylated glycerol kinase, but no third band, was observed when reaction mixtures containing between 1 and $8 \mu \mathrm{M}$ PEP were separated on SDS polyacrylamide gels (data not shown). Since bacterial glycerol kinases are known 

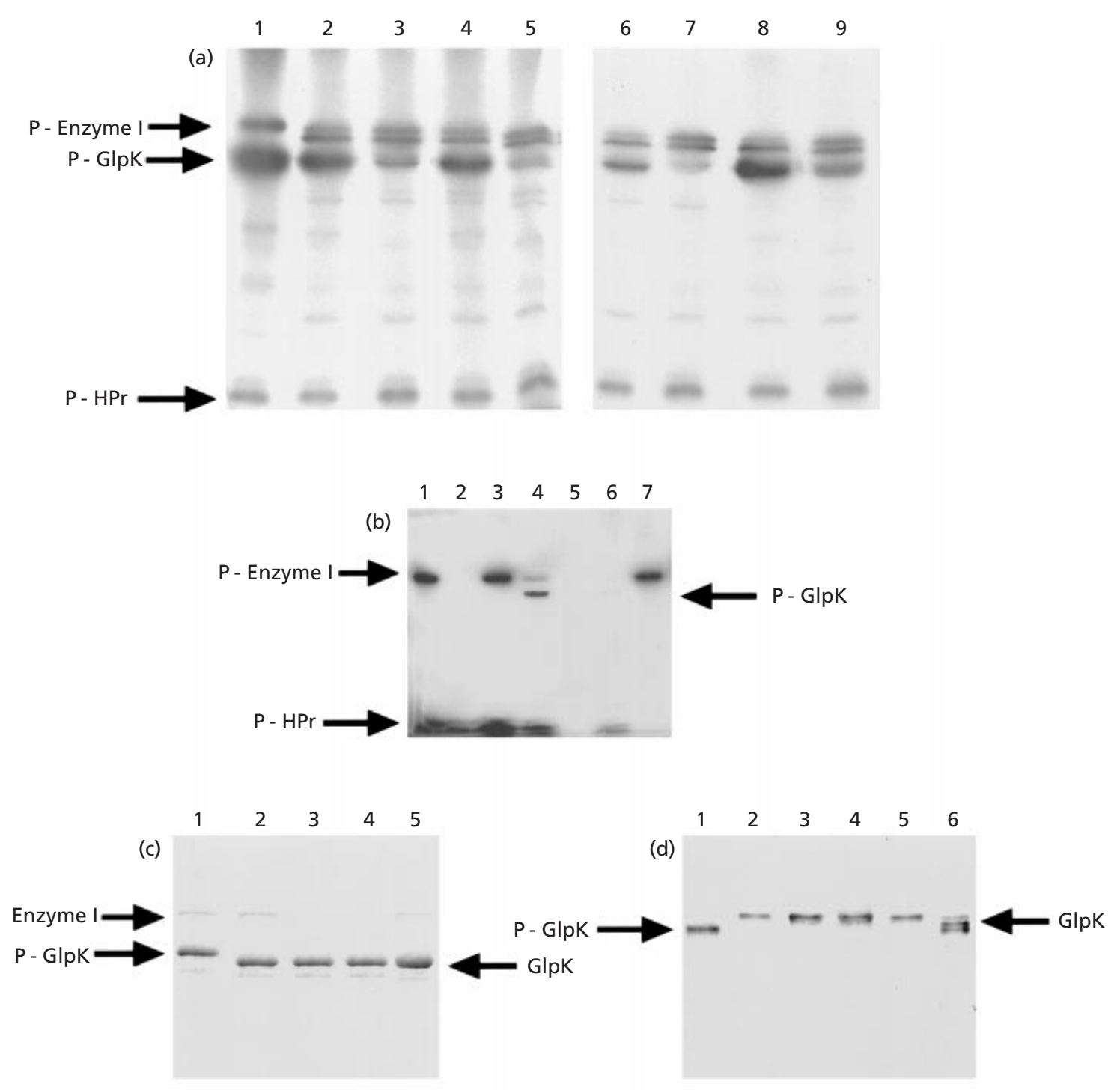

Fig. 3. Phosphorylation of glycerol kinase (GIpK) with [32P]PEP or PEP. The phosphorylation assays $(30 \mu \mathrm{l})$ contained either

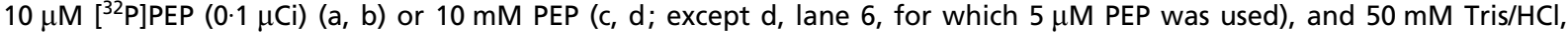
$\mathrm{pH} 7 \cdot 4,10 \mathrm{mM} \mathrm{MgCl}$ and varying mixtures of the following proteins: $4 \mu \mathrm{g}$ glycerol kinase from $T$. flavus, $0.5 \mu \mathrm{g}$ enzyme I(His) from $B$. subtilis, $0.5 \mu \mathrm{g} H \operatorname{Pr}(\mathrm{His})_{6}$ from $B$. subtilis or $6 \mu \mathrm{l}$ crude $T$. flavus extract. The assay mixtures were incubated for $20 \mathrm{~min}$ at $37{ }^{\circ} \mathrm{C}$. Sample buffer was added to phosphorylation assays containing [ $\left.{ }^{32} \mathrm{P}\right]$ PEP. These samples were separated on denaturing $12.5 \%$ polyacrylamide gels ( $1 \%$ SDS), which were subsequently dried and exposed to autoradiography $(a, b)$, whereas samples containing PEP were separated either on denaturing (1\% SDS) (c) or nondenaturing (d) $10 \%$ polyacrylamide gels, which were stained with Coomassie Brilliant Blue R. The samples loaded on the different lanes contained the following proteins. (a) Lane 1, enzyme I and HPr from B. subtilis and glycerol kinase from T. flavus; lane 2, glycerol kinase and crude extract of cells grown on $2 \times \mathrm{YT}$; lane 3, crude extract of cells grown on $2 \times \mathrm{YT}$; lane 4, glycerol kinase and crude extract of glycerol-grown cells; lane 5, crude extract of glycerol-grown cells; lane 6, glycerol kinase and crude extract of glucose-grown cells; lane 7, crude extract of glucose-grown cells; lane 8; glycerol kinase and crude extract of fructose-grown cells; lane 9; crude extract of fructose-grown cells. (b) Lane 1, enzyme l; lane 2, HPr; lane 3, enzyme I and HPr; lane 4, enzyme I, HPr and glycerol kinase; lane 5, HPr and glycerol kinase; lane 6, glycerol kinase; lane 7, enzyme I and glycerol kinase. (c) Lane 1, enzyme I, HPr and glycerol kinase; lane 2, enzyme I and glycerol kinase; lane 3, HPr and glycerol kinase; lane 4, glycerol kinase; lane 5, enzyme I, HPr and glycerol kinase (without PEP). (d) Lane 1, enzyme I, HPr and glycerol kinase; lane 2, enzyme I and glycerol kinase; lane 3, HPr and glycerol kinase; lane 4, glycerol kinase; lane 5, enzyme I, HPr and glycerol kinase (without PEP); lane 6, enzyme I, HPr and glycerol kinase (with $5 \mu \mathrm{M}$ PEP). P, phosphorlated.

to be composed of identical subunits (Hurley et al., 1993), we supposed that the third band observed on nondenaturing gels after separation of phosphorylation mixtures containing low concentrations of PEP corre- sponds to glycerol kinase molecules in which not all subunits are phosphorylated. By carrying out sizeexclusion chromatography on an FPLC column (Superdex 200 pg; Pharmacia) with high resolution in the 
$100 \mathrm{kDa}$ range, we could demonstrate that native $T$. flavus glycerol kinase is composed of two identical subunits and not, as has previously been reported, four subunits (Huang et al., 1997). It is therefore likely that the third band observed only on non-denaturing polyacrylamide gels after separation of phosphorylation mixtures containing limiting amounts of PEP and migrating between unphosphorylated and completely phosphorylated glycerol kinase (Fig. 3d, lane 6) corresponds to glycerol kinase dimers in which only one of the two subunits is phosphorylated.

\section{Effect of phosphorylation of $T$. flavus glycerol kinase on its enzyme activity.}

PEP-dependent, enzyme I- and HPr-catalysed phosphorylation of enterococcal glycerol kinases caused a 10-fold increase in enzyme activity (Deutscher, 1985; Charrier et al., 1997). We therefore wanted to test whether phosphorylation of T. flavus glycerol kinase would lead to a similar stimulation with regard to its enzyme activity. T. flavus glycerol kinase was phosphorylated with PEP, enzyme I and HPr as described in Methods, and glycerol kinase assays were carried out using saturating concentrations of glycerol $(5 \mathrm{mM})$ and ATP $(5 \mathrm{mM})$. The $K_{\mathrm{m}}$ values of $T$. flavus glycerol kinase for glycerol and ATP have been reported to be 38 and $162 \mu \mathrm{M}$, respectively (Huang et al., 1997). Under the above conditions, very similar activities were found for unphosphorylated $(4 \cdot 4$ units $)$ and phosphorylated glycerol kinase (5.6 units). In contrast to enterococcal glycerol kinases, phosphorylation of T. flavus glycerol kinase does not seem to increase the $V_{\max }$ of this enzyme. The observed absence of a stimulatory effect of PEP-dependent phosphorylation of glycerol kinase on its enzyme activity cannot be due to incomplete phosphorylation of $T$. flavus glycerol kinase under the reaction conditions employed. When an aliquot of the phosphorylated $T$. flavus glycerol kinase used for the activity assays was separated on SDS polyacrylamide gels, more than $90 \%$ of the glycerol kinase was found to be present in the phosphorylated form (data not shown).

\section{DISCUSSION}

When proteins with identical function from $T$. flavus and $B$. subtilis were compared, they exhibited sequence identities between 30 and $50 \%$ (data not shown). The much higher degree of sequence identity observed for the glycerol kinases $(80 \cdot 6 \%)$ and the N-terminal 156 amino acid fragment of the glycerol facilitators $(64.0 \%)$ from these two distantly related organisms suggested that $T$. flavus might have gained the glp operon by horizontal gene transfer from a bacillus species or an organism closely related to bacilli. The $g l p$ operon seems to be expressed in T. flavus and both proteins encoded by the $g l p$ operon seem to be active, as glycerol kinase activity can be detected in crude extracts of $T$. flavus cells and as T. flavus cells can transport glycerol. Glycerol transport was found to be reduced when cells were grown in the presence of glucose. Our experiments do not exclude the possibility that glucose exerts its repressive effect not on glycerol transport directly but on an early step of glycerol metabolism. Since glycerol is transported by facilitated diffusion, inhibition of its first metabolic steps will probably also reduce the uptake of glycerol.

Most glycerol kinases from Gram-positive bacteria, but not glycerol kinases from Gram-negative bacteria, seem to be regulated by a mechanism that implicates stimulation of glycerol kinase activity by PEP-dependent phosphorylation at a histidyl residue catalysed by enzyme I and HPr of the PTS (Deutscher \& Sauerwald, 1986; Charrier et al., 1997). As a consequence, $p t s H$ or ptsI mutants of Gram-positive bacteria, in which glycerol kinase cannot be activated by PEP-dependent phosphorylation, were unable to grow on glycerol as the sole carbon source (Reizer et al., 1984; Romano et al., 1990; Gonzy-Treboul et al., 1991; Beijer \& Rutberg, 1992). Interestingly, the phosphorylatable histidyl residue was also found to be present in glycerol kinase from $T$. flavus. The sequences flanking this histidyl residue are well-conserved when compared to the corresponding sequences of glycerol kinase from B. subtilis (Fig. 2) or other Gram-positive bacteria. In the presence of $\left[{ }^{32} \mathrm{P}\right] \mathrm{PEP}$, purified $T$. flavus glycerol kinase was found to be phosphorylated by crude extracts of $T$. flavus cells (Fig. 3a), suggesting that this organism contains the general PTS proteins enzyme I and HPr. This assumption was confirmed by the observation that crude extracts prepared from T. flavus cells were capable of reconstituting the lactose-specific PTS activity in mutant complementation assays with $S$. aureus $p t s I$ and $p t s H$ mutants (Hengstenberg et al., 1969). Deinococcus radiodurans, a close relative of $T$. flavus, was found to possess a multiphosphoryl transfer protein (MTP) similar to Rhodobacter capsulatus (Wu et al., 1990) and Xanthomonas campestris (de Crécy-Lagard et al., 1995). The MTP is part of the fructose-specific PTS and contains an enzyme IIA ${ }^{\text {Fru }}$ domain followed by an HPr and an enzyme I domain. The sequence around the phosphorylatable histidyl residue in the HPr domain of $D$. radiodurans was found to exhibit strong similarity to the corresponding sequence in $B$. subtilis $\mathrm{HPr}$ (data not shown). However, the experiments presented in Fig. 3a suggest that $T$. flavus does not possess an MTP, but that enzyme I and HPr of this organism are probably distinct proteins, as radioactive bands migrating to the approximate positions of enzyme I and $\mathrm{HPr}$ from $B$. subtilis were detected when crude extracts of T. flavus were incubated with $\left[{ }^{32} \mathrm{P}\right] \mathrm{PEP}$ and separated by SDSPAGE. Even in fructose-grown cells (Fig. 3a, lanes 8 and 9), no labelled band migrating to the position corresponding to the molecular mass of the MTP $(90 \mathrm{kDa})$ was observed. However, similar to the HPr domain of $D$. radiodurans $\mathrm{MTP}, \mathrm{HPr}$ of $T$. flavus probably possesses an active centre strongly resembling the active centre of $\mathrm{HPr}$ in Gram-positive bacteria, which would explain why HPr present in crude extracts prepared from $T$. flavus cells is functional in the $S$. aureus mutant- 
complementation assay with the pts $H$ mutant S797A and why P-His-HPr from both B. subtilis and T. flavus can efficiently phosphorylate $T$. flavus glycerol kinase.

Although phosphorylation of glycerol kinase changes the electrophoretic mobility of T. flavus glycerol kinase in a similar way to that which has been observed for glycerol kinase from Ent. faecalis (Deutscher \& Sauerwald, 1986; Charrier et al., 1997), only a very weak stimulation of glycerol kinase activity was found to accompany phosphorylation of T. flavus glycerol kinase. The physiological function of the PEP-dependent PTScatalysed phosphorylation of $T$. flavus glycerol kinase therefore remains unknown. It is interesting to note that glycerol kinase from another thermophilic organism, Bacillus stearothermophilus, exhibited a very similar behaviour to $T$. flavus glycerol kinase. It was also phosphorylated by PEP, enzyme I and HPr, and phosphorylation caused changes in electrophoretic mobility identical to those found with T. flavus glycerol kinase (Reizer \& Peterkofsky, 1987). In addition, no increase in enzyme activity was observed when B. stearothermophilus glycerol kinase became phosphorylated. It is possible that phosphorylation of glycerol kinase in the two thermophilic organisms T. flavus and B. stearothermophilus causes an increase in enzyme activity only at higher temperatures. Since no thermostable glycerol3-phosphate dehydrogenase was available, the enzyme assays reported in this paper were carried out at $37^{\circ} \mathrm{C}$ and not at the preferred temperature of T. flavus, i.e. $60{ }^{\circ} \mathrm{C}$. It is interesting to note that when phosphorylated glycerol kinase from $\mathrm{T}$. flavus was kept at $60^{\circ} \mathrm{C}$ in Tris/ $\mathrm{HCl}$ buffer, $\mathrm{pH} 7 \cdot 4$, about $70 \%$ of the protein was dephosphorylated within $10 \mathrm{~min}$, as was observed with other proteins phosphorylated at the N-3 position of a histidyl residue (Waygood et al., 1986). However, the remaining $30 \%$ of the protein was found to remain phosphorylated even after $1 \mathrm{~h}$ incubation at $60^{\circ} \mathrm{C}$ (data not shown). It is possible that under physiological conditions, most of the T. flavus glycerol kinase is converted into this phosphorylated, heat-resistant form, which might exhibit elevated enzyme activity.

After this paper was accepted, we noticed when carrying out BLAST searches with the amino acid sequence of $T$. flavus glycerol kinase in microbial databases that $D$. radiodurans, a close relative of $T$. flavus, contains two glycerol kinases: one without the conserved phosphorylatable histidyl residue of Gram-positive bacteria, rather resembling Esc. coli glycerol kinase $(58 \%$ sequence identity), the other possessing an equivalent of His-232 and exhibiting an unexpectedly high sequence identity of $88 \%$ to glycerol kinase from Streptococcus pyogenes. D. radiodurans possesses an MTP, which is composed of a fructose-specific EIIA, an HPr and an enzyme I domain (Wu et al., 1990). It is therefore likely that the His-232-containing glycerol kinase of this organism is also phosphorylated in vivo with PEP.

\section{ACKNOWLEDGEMENTS}

We are thankful to Dominique Le Coq for critically reading the manuscript. This research was supported by the Centre
National de la Recherche Scientifique, the Institut National Agronomique, Paris-Grignon and by the Institut National de la Recherche Agronomique. Preliminary D. radiodurans sequence data were obtained from The Institute for Genomic Research through the website at http://www.tigr.org. Sequencing of the $D$. radiodurans project was accomplished with the support from the US Department of Energy.

\section{REFERENCES}

Anagnostopoulos, C. \& Spizizen, J. (1961). Requirements for transformation in Bacillus subtilis. J Bacteriol 81, 741-746.

Beijer, L. \& Rutberg, L. (1992). Utilisation of glycerol and glycerol 3 -phosphate is differently affected by the phosphotransferase system in Bacillus subtilis. FEMS Microbiol Lett 79, 217-220.

Charrier, V., Buckley, E., Parsonage, D., Galinier, A., Darbon, E., Jaquinod, M., Forest, E., Deutscher, J. \& Claiborne, A. (1997). Cloning and sequencing of two enterococcal $g l p K$ genes and regulation of the encoded glycerol kinases by phosphoenolpyruvate-dependent, phosphotransferase system-catalyzed phosphorylation of a single histidyl residue. J Biol Chem 272, 14166-14174.

de Crécy-Lagard, V., Binet, M. \& Danchin, A. (1995). Fructose phosphotransferase system of Xanthomonas campestris pv. campestris: characterization of the fruB gene. Microbiology $\mathbf{1 4 1 ,}$ 2253-2260.

De Boer, M., Broekhuizen, C. P. \& Postma, P. W. (1986). Regulation of the glycerol kinase by enzyme III ${ }^{\mathrm{Glc}}$ of the phosphoenolpyruvate: carbohydrate phosphotransferase system. J Bacteriol 67, 393-395.

Deutscher, J. (1985). Phosphoenolpyruvate-dependent phosphorylation of a $55 \mathrm{kDa}$ protein of Streptococcus faecalis catalysed by the phosphotransferase system. FEMS Microbiol Lett 29, 237-243.

Deutscher, J. \& Sauerwald, H. (1986). Stimulation of dihydroxyacetone and glycerol kinase activity in Streptococcus faecalis by phosphoenolpyruvate-dependent phosphorylation catalyzed by enzyme I and HPr of the phosphotransferase system. J Bacteriol 166, 829-836.

Deutscher, J., Bauer, B. \& Sauerwald, H. (1993). Regulation of glycerol metabolism in Enterococcus faecalis by phosphoenolpyruvate-dependent phosphorylation of glycerol kinase catalyzed by enzyme I and HPr of the phosphotransferase system. J Bacteriol 175, 3730-3733.

Galinier, A., Haiech, J., Kilhoffer, M. C., Jaquinod, M., Stülke, J., Deutscher, J. \& Martin-Verstraete, I. (1997). The Bacillus subtilis crh gene encodes an HPr-like protein involved in carboncatabolite repression. Proc Natl Acad Sci USA 94, 8439-8444.

Gonzy-Treboul, G., de Waard, J. H., Zagorec, M. \& Postma, P. W. (1991). The glucose permease of the phosphotransferase system of Bacillus subtilis: evidence for $\mathrm{II}^{\mathrm{Gle}}$ and $\mathrm{III}^{\mathrm{Glc}}$ domains. Mol Microbiol 5, 1241-1249.

Heller, K. B., Lin, E. C. C. \& Wilson, T. H. (1980). Substrate specificity and transport properties of the glycerol facilitator of Escherichia coli. J Bacteriol 144, 274-278.

Hengstenberg, W., Penberthy, W. K., Hill, K. L. \& Morse, M. L. (1969). Phosphotransferase system of Staphylococcus aureus: its requirement for the accumulation and metabolism of galactosides. J Bacteriol 99, 383-388.

Holmberg, C., Beijer, L., Rutberg, B. \& Rutberg, L. (1990). Glycerol catabolism in Bacillus subtilis: nucleotide sequence of the genes encoding glycerol kinase $(g l p K)$ and glycerol-3-phosphate dehydrogenase $(g l p D)$. J Gen Microbiol 136, 2367-2375. 
Huang, H. S., Yoshida, T., Meng, Y., Kabashima, T., Ito, I., Nishiya, Y., Kawamura, Y. \& Yoshimoto, T. (1997). Purification and characterization of thermostable glycerol kinase from Thermus flavus. J Ferment Bioeng 83, 328-332.

Huang, H. S., Kabashima, T., Ito, K., Yin, C. H., Nishiya, Y., Kawamura, Y. \& Yoshimoto, T. (1998a). Thermostable glycerol kinase from Thermus flavus : cloning, sequencing, and expression of the enzyme gene. Biochim Biophys Acta 1382, 186-190.

Huang, H. S., Ito, K., Yin, C. H., Kabashima, T. \& Yoshimoto, T. (1998b). Cloning, sequencing, high expression, and crystallization of the thermophile Thermus aquaticus glycerol kinase. Biosci Biotechnol Biochem 62, 2375-2381.

Hurley, J. H., Faber, H. R., Worthylake, D., Meadow, N. D., Roseman, S., Pettigrew, D. W. \& Remington, S. J. (1993). Structure of the regulatory complex of Escherichia coli $\mathrm{III}^{\mathrm{Gle}}$ with glycerol kinase. Science 259, 673-677.

Kalbitzer, H. R., Hengstenberg, W., Rösch, P., Muss, P., Bernsmann, P., Engelmann, R., Dörschug, M. \& Deutscher, J. (1982). HPr proteins of different microorganisms studied by hydrogen-1 high resolution nuclear magnetic resonance: similarities of structures and mechanisms. Biochemistry 21, 2879-2885.

Laemmli, U. K. (1970). Cleavage of structural proteins during the assembly of the head of bacteriophage T4. Nature 227, 680-685.

Lin, E. C. C. (1976). Glycerol dissimilation and its regulation in bacteria. Annu Rev Microbiol 30, 535-578.

Reizer, J. \& Peterkofsky, A. (1987). Regulatory mechanisms for sugar transport in Gram-positive bacteria. In Sugar Transport and Metabolism in Gram-Positive Bacteria, pp. 333-364. Edited by J. Reizer \& A. Peterkofsky. Chichester, UK: Ellis Horwood.

Reizer, J., Novotny, M. J., Stuiver, I. \& Saier, M. H., Jr (1984). Regulation of glycerol uptake by the phosphoenolpyruvate-sugar phosphotransferase system in Bacillus subtilis. J Bacteriol 159, 243-250.

Romano, A. H., Saier, M. H., Jr, Harriott, O. T. \& Reizer, J. (1990). Physiological studies on regulation of glycerol utilization by the phosphoenolpyruvate: sugarphosphotransferasesysteminEnterococcus faecalis. J Bacteriol 172, 6741-6748.

Roossien, F. F., Brink, J. \& Robillard, G. T. (1983). A simple procedure for the synthesis of $\left[{ }^{32} \mathrm{P}\right]$ phosphoenolpyruvate via the pyruvate kinase exchange reaction at equilibrium. Biochim Biophys Acta 760, 185-187.

Saier, M. H., Jr, Simoni, R. D. \& Roseman, S. (1976). Sugar transport. IX. Properties of mutant bacteria defective in proteins of the phosphoenolpyruvate : sugar phosphotransferase system. $J$ Biol Chem 251, 6584-6597.

Sambrook, J., Fritsch, E. F. \& Maniatis, T. (1989). Molecular Cloning: a Laboratory Manual, 2nd edn. Cold Spring Harbor, NY : Cold Spring Harbor Laboratory.

van der Vlag, J., van Dam, K. \& Postma, P. W. (1994). Quantification of the regulation of glycerol and maltose metabolism by IIA $^{\text {Gle }}$ of the phosphoenolpyruvate-dependent glucose phosphotransferase system in Salmonella typhimurium. J Bacteriol 176, 3518-3526.

Waygood, E. B., Mattoo, R. L., Erickson, E. \& Vadeboncoeur, C. (1986). Phosphoproteins and the phosphoenolpyruvate:sugar phosphotransferase system of Streptococcus salivarius: detection of two different ATP-dependent phosphorylations of the phosphocarrier protein HPr. Can J Microbiol 32, 310-318.

Wehtje, C., Beijer, L., Nilsson, R. P. \& Rutberg, B. (1995). Mutations in the glycerol kinase gene restore the ability of a ptsGHI mutant of Bacillus subtilis to grow on glycerol. Microbiology 141, 1193-1198.

Wu, L.-F., Tomich, J. M. \& Saier, M. H., Jr (1990). Structure and evolution of a multidomain multiphosphoryl transfer protein: nucleotide sequence of the fruB(HI) gene in Rhodobacter capsulatus and comparisons with homologous genes from other organisms. J Mol Biol 213, 687-703.

Received 1 June 1999; revised 19 July 1999; accepted 23 July 1999. 